\title{
STUDI EKSPERIMEN BUAH BELIMBING WULUH MENJADI SORBET
}

\author{
Ni Putu Mas Yudayani, Damiati, Luh Masdarini \\ Jurusan Pendidikan Kesejahteraan Keluarga \\ Universitas Pendidikan Ganesha \\ Singaraja, Indonesia
}

e-mail : yanigex@gmail.com,damiati@undiksha.ac.id, masdarini@undiksha.ac.id

\begin{abstract}
Abstrak
Penelitian eksperimen ini bertujuan untuk mengetahui (1) formulasi resep baku sorbet buah belimbing wuluh (2) kualitas sorbet dari aspek tekstur dan aspek rasa. Penelitian ini adalah penelitian eksperimen. Metode yang digunakan untuk mendapatkan data adalah metode observasi. Sorbet buah belimbing wuluh dari aspek tekstur dan aspek rasa diuji oleh 25 panelis terlatih dengan menggunakan intrumen berupa lembar uji organoleptik dengan 3 tingkatan yaitu baik, cukup, buruk. Kemudian dianalisi melalui analisis deskriptif kuantitatif. Hasil menunjukkan (1) formulasi resep baku sorbet buah belimbing wuluh dengan bahan utama belimbing wuluh $500 \mathrm{gr}$, gula pasir $300 \mathrm{gr}$ dan air $100 \mathrm{ml}$. kualitas sorbet buah belimbing wuluh dilihat dari aspek tekstur berada dalam kategori baik dengan skor $(2,64)$ yaitu memiliki tekstur kasar dan berserat (2) kualitas sorbet buah belimbing wuluh dilihat dari aspek rasa berada dalam kategori baik dengan skor $(2,60)$ yaitu memiliki rasa manis, keasaman.
\end{abstract}

Kata kunci: buah belimbing wuluh, sorbet, tekstur, rasa

\section{Abstract}

This experimental research is aimed to find out (1) the recipe formulation of raw sorbet of star fruit (2) sorbet quality from texture aspect and taste aspect. This research is experimental research. The method used to obtain data is the method of observation. Sorbet of starfruit from texture aspect and taste aspect tested by 25 panel of trained by using instrument in the form of organoleptic test sheet with 3 levels that is good, enough, bad. Then it is analyzed through quantitative descriptive analysis. The results showed (1) prescription formulation of raw sorbet star fruit starfruit with main ingredient starfruit wuluh $500 \mathrm{gr}, 300 \mathrm{gr}$ sugar and water $100 \mathrm{ml}$. the quality of star fruit sorbet wuluh seen from the texture aspect is in good category with score $(2,64)$ that has coarse texture and fibrous (2) quality sorbet of star fruit wuluh seen from flavor aspect are in good category with score $(2,60)$ that is has a sweet taste, acidity.

Keywords: star fruit, sorbet, texture, flavor

\section{PENDAHULUAN}

Buah adalah salah satu bahan makanan yang dibutuhkan oleh tubuh manusia karena buah banyak mengandung vitamin, mineral dan zat besi. Namun, pada masa panen tidak sedikit buah yang terbuang percuma akibat busuk. Karena itu, dibutuhkan cara mengolah buah menjadi produk yang lebih awet dan bernilai jual tinggi. Ada beberapa buah yang bersifat musiman seperti rambutan, durian, salak, mangga, dan sebagainya. Namun ada juga buah yang bersifat sepanjang musim seperti pepaya, pisang, kedondong dan belimbing wuluh.
Belimbing berasal dari family Oxalidaceae, Averrhoa. Belimbing dibagi menjadi dua jenis, yaitu belimbing manis (Averrhoa carambola) dan Belimbing Asam (Averrhoa bilimbi) yang sering disebut dengan belimbing wuluh (Lingga, 1990).

Buah belimbing wuluh digunakan sebagai sirop penyegar atau bahan penyedap makanan (Wijayakusuma, 2004). Rasa asam dan segar dari buah belimbing wuluh sering dimanfaatkan sebagai pelengkap bumbu dapur, sebagai obat tradisional, selain itu juga dimanfaatkan menjadi manisan kering yang sebelumnya diteliti oleh Fitriani (2008) berdasarkan hasil pengamatannya 
diketaui bahwa suhu dan lama pengeringan serta interaksi antara suhu dan lama pengeringan berpengaruh terhadap kadar air manisan belimbing wuluh yang kering.

Keunggulan belimbing wuluh yaitu sangat mudah diperoleh dan juga aman dikonsumsi dan dapat menurunkan tekanan darah (Santosa dan Gunawan, 2005). Kandungan buah belimbing wuluh yaitu kalium sitrat, selain itu juga mengandung vitamin C. Kadar air yang tinggi menyebabkan buah ini mudah rusak dan memiliki daya simpan yang rendah 45 hari, (Agustin dan Putri, 2014). Belimbing wuluh termasuk tanaman yang berbuah sepanjang tahun atau tidak musiman dan berbuah sangat banyak. Belimbing wuluh yang dapat berbuah sepanjang tahun tersebut tidak diimbangi dengan pemanfaatannya secara optimal, sehingga buah ini sering terbuang begitu saja. Untuk itu diperlukan suatu proses pengolahan sehingga belimbing wuluh memiliki masa simpan yang panjang. Rasa yang sangat asam membuat buah belimbing wuluh jarang dikonsumsi secara segar. Masyarakat biasanya hanya memanfaatkan buah belimbing sebagai bumbu masakan, di jual di pasar dan digunakan untuk obat dan di buat menjadi manisan. Pemanfaatan buah tersebut dapat dibuat menjadi produk olahan agar buah belimbing wuluh tidak terbuang secara percuma dan dapat mempertahankan masa simpan menjadi lebih lama. Kandungan gizi yang terdapat pada belimbing wuluh dijelaskan secara rinci pada Table 1. berikut:

Tabel 1.Kandungan Gizi Buah Belimbing Wuluh Per 100 Gram

\begin{tabular}{ll}
\hline \multicolumn{1}{c}{ Komposisi gizi } & \multicolumn{1}{c}{ Proporsi } \\
\hline Kadar air & $94,1 \mathrm{~g}$ \\
Protein & $0,7 \mathrm{~g}$ \\
Lemak & $0,2 \mathrm{~g}$ \\
Karbohidrat & $4,7 \mathrm{~g}$ \\
Serat & $0,6 \mathrm{~g}$ \\
Kalsium & $7 \mathrm{mg}$ \\
Fosfor & $11 \mathrm{mg}$ \\
Zat besi & $0,4 \mathrm{mg}$ \\
Vitamin A & $145 \mathrm{I.U}$ \\
Vitamin C & $25 \mathrm{mg}$ \\
Asam askobat & $9 \mathrm{mg}$ \\
\hline (Sumber: Subhadrabandhu 2001 )
\end{tabular}

Berdasarkan kandungan zat gizi yang ada pada buah belimbing wuluh dapat dilihat bahwa buah belimbing wuluh memiliki kadar lemak yang rendah $(0,2 \mathrm{~g})$ yang didukung dengan protein $(0,7 \mathrm{~g})$ dan karbohidrat $(4,7 \mathrm{~g})$ sehingga sangat tepat digunakan sebagai minuman sorbet dimana kriteria dari sorbet adalah rendah lemak karena sorbet menjadi alternatif pengganti es krim untuk mereka yang sedang melakukan diet (Primarasa, 2009). Selain itu buah belimbing wuluh belum dimanfaatkan secara maksimal, belimbing wuluh umumnya dimanfaatkan selagi masih segar yang hanya di jual di pasarpasar tradisional untuk bumbu (Santosa, 2005). Dilihat dari kurangnya pemanfaatan buah belimbing wuluh peneliti tertarik untuk membuat olahan berupa minuman sorbet. Sebelumnya Agustin dan Putri (2014) melakukan penelitian menggunakan buah belimbing wuluh dengan judul "Pembuatan Jelly drink Averrhoa blimbi L. (Kajian Proporsi Belimbing wuluh : Air dan Konsentrasi Karagenan)" hasil yang di peroleh dalam penelitiannya bahwa buah belimbing wuluh memiliki manfaat yang baik untuk tubuh karena kandungan vitamin $\mathrm{C}$ yang tinggi.

Menurut kamus besar bahasa Indonesia sorbet merupakan minuman segar, dibuat dari sari buah (biasanya buah setrun) ditambah gula dan sebagainya. Sorbet terbuat dari campuran buah segar dan pemanis yang dibekukan. Pemanis yang biasa digunakan berupa, gula, sirup gula, gula bubuk dan madu. 
Tekstur sorbet lebih kasar dibandingkan dengan es krim karena tidak mengandung emulsifier (Rosita,2016). Sekarang ini sorbet juga dihidangakan pada acara makan siang sebagai minuman dingin disertai makanan ringan. Sorbet buah dalam pembuatannya biasanya ditambah dengan jus buah. Seluruh jenis sorbet rasanya segar dan kurang begitu manis jika dibandingkan dengan es krim. Penyajian sorbet dapat juga dikombinasikan dengan meringue atau krim di atasnya (Faridah dkk, 2008). Sorbet dipilih karena tidak menggunakan susu sebagai bahan utamanya. Bahkan untuk yang sedang berdiet juga terdapat sorbet yang tidak ditambahkan gula sama sekali dan digantikan dengan gula diet (Winneke, 2008) buah yang dapat dijadikan bahan baku sorbet sebaiknya buah segar, berserat dan tidak rusak. Contoh buah-buahan yang dapat dibuat sorbet adalah mangga, nanas, melon, strawberry dan lemon. Dalam pembuatan sorbet buah yang kurang asam dapat ditambahkan dengan asam sitrat atau sari lemon sehingga dapat beroleh rasa yang asam yang sesuai dengan karakteristik dari sorbet. Dahulu sorbet sering disajikan sebagai hidangan penyegar antara dua hidangan berat, namun sekarang juga disajikan sebagai hidangan penutup.

Buah belimbing wuluh yang dimanfaatkan menjadi produk minuman sorbet bertujuan untuk mereka yang melakukan diet dan sebagai pengembangan keanekaragaman produk olahan buah belimbing wuluh. Buah belimbing wuluh digunakan karena buah belimbing tidak musiman dan sangat mudah dicari tetapi masyarakat tidak memanfaatkan buah belimbing wuluh secara optimal dan minuman sorbet belum terlalu dikenal oleh masyarakat pada umunya sedangkan pembuatan sorbet itu sangat mudah dan bahan yang digunakan tergolong murah, sehingga peneliti ingin memperkenalkan produk olahan sorbet yang menggunakan bahan utamanya adalah buah belimbing wuluh. Pembuaatan sorbet buah belimbing wuluh mengacu pada resep sorbet mangga. Resep adalah takaran yang digunakan untuk membuat masakan (makanan atau minuman) yang telah teruji ke akuratannya. Bahan yang digunakan dalam pembuatan sorbet mangga arumanis yaitu $1400 \mathrm{gr}$ buah mangga arumanis, 200 gr gula pasir, glukosa, sari lemon $70 \mathrm{gr}$ dan $100 \mathrm{ml}$ air dan hasil yang didapatkan dalam pembuatan sorbet mangga terdapat dua kriteria yaitu dari segi rasa dan tekstur, rasa yang didapatkan dari sorbet mangga memiliki rasa manis keasaman, rasa manis keasaman ini didapatkan dari pencampuran bahan dari pembuatan sorbet mangga arumanis, yang kedua tekstur yang didapatkan berupa tekstur kasar dan berserat. Mengacu dari resep sorbet mangga dalam penelitian ini sorbet yang akan dibuat menggunakan bahan utama berupa buah belimbing wuluh.

Berdasarkan latar belakang di atas maka peneliti akan membuat eksperimen pembuatan sorbet buah belimbing wuluh. Dalam pembuatan sorbet teknik yang digunakan yaitu teknik pendinginan, bahan utama dalam pembuatan sorbet yaitu sari buah, yang direbus dengan bahan tambahan gula hingga mendidih setelah itu diamkan hingga dingin dan masukkan kedalam mesin ice cream selama 15 menit. Berdasarkan pemaparan di atas, peneliti tertarik untuk mengadakan penelitian dengan judul "Studi Eksperimen buah belimbing wuluh menjadi Sorbet".

\section{METODE}

Metode yang digunakan dalam penelitian ini adalah metode observasi. Metode observasi adalah suatu cara memperoleh data dengan jalan mengadakan pengamatan dan pencatatan secara sistematis tentang suatu objek tertentu. Penelitian dengan metode observasi untuk mengumpulkan data dimulai dengan pencarian informasi mengenai bahan penelitian yaitu buah belimbing wuluh dan bagaimana cara mengolahnya. Selain itu metode observasi juga digunakan untuk mengumpulkan data tentang kualitas sorbet buah belimbing wuluh ditinjau dari aspek tekstur dan rasa dengan alat berupa lembar observasi uji kualitas. Data yang terkumpul kemudian dianalisis sehingga memperoleh kesimpulan. 
Jurnal Bosaparis: Pendidikan Kesejahteraan Keluarga

Volume 9, Nomor 1, Maret 2018

Penelitian terhadap sorbet buah Belimbing wuluh menggunakan uji organoleptik berupa penilaian tekstur dan rasa. Uji organoleptik merupakan penilaian dengan menggunakan indra manusia. Uji organoleptik yang digunakan dalam penelitian ini adalah uji mutu hedonik. "Uji mutu hedonik merupakan uji yang dilakukan oleh panelis untuk menanggapi tentang kesan baik buruk suatu produk makanan" (Soekarto, 1985). Dalam penelitian ini menggunakan panelis terlatih anggota panelis terlatih lebih besar dari anggota panelis pencicip terbatas. Panelis terlatih terdiri dari $15-25$ orang yang mempunyai kepekaan cukup baik. Pada penelitian ini penulis menggunakan
25 orang panelis terlatih yang terdiri dari 2 orang dosen Jurusan Pendidikan Kesejahteraan Keluarga, 12 orang Guru Tata Boga di SMK Negeri 2 Singaraja, 3 orang guru di SMK Triatmajaya Singaraja, dan 8 orang yang berasal dari industri perhotelan.

Dalam penelitian ini instrumen yang digunakan berupa lembar observasi uji kualitas sorbet buah belimbing wuluh yang akan diberikan kepada setiap panelis untuk menilai kualitas produk yang disajikan.

Skala mutu hedonik dalam penelitian ini menggunakan 3 (tiga) rentangan skala sebagai berikut:

Tabel 2. Skala Mutu Hedonik dan Skala Numerik

\begin{tabular}{lc}
\hline Skala Mutu Hedonik & Skala numerik \\
\hline Baik & 3 \\
Cukup & 2 \\
Buruk & 1 \\
\hline
\end{tabular}

Sumber: Soekarto (1985:80)

Untuk mendapatkan tanggapan terhadap hasil dari responden maka dari itu dibuat tolok ukur dan lembar uji kualitas dari sorbet buah belimbing wuluh. Dan adapun tolok ukur uji kualitas sorbet buah belimbing wuluh sebagai berikut

Tabel 4. Tolok ukur uji kualitas sorbet

\begin{tabular}{cll}
\hline Nilai & \multicolumn{1}{c}{ Tekstur } & \multicolumn{1}{c}{ Rasa } \\
\hline 3 & Kasar dan berserat & Manis, keasaman \\
2 & Salah satu terpenuhi & Salah satu terpenuhi \\
1 & Semua tidak terpenuhi & $\begin{array}{l}\text { Semua } \\
\text { terpenuhi }\end{array}$ \\
& & tidak \\
\hline
\end{tabular}

Tabel 5. Lembar observasi uji kualitas sorbet buah belimbing wuluh

Tanggal

Panelis.

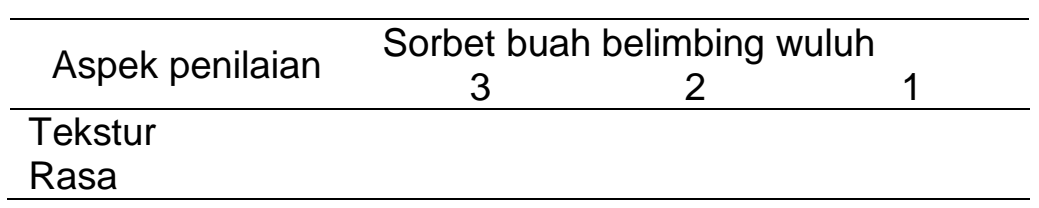

Dalam penelitian sorbet buah belimbing wuluh ini menggunakan uji organoleptik yang meliputi tekstur dan rasa. Pada uji organoleptik yang digunakan dalam penelitian ini adalah uji mutu hedonik, pada uji mutu hedonik ini panelis diminta tanggapan pribadinya tentang kesan baik buruknya hasil suatu produk makanan.
Dalam penilaian dapat dianalisis secara statistik, panelis akan menanggapi dengan cara memberikan tanda check list $(\sqrt{ })$ sesuai kriteria yang telah ditentukan pada formulasi uji kualitas sorbet buah belimbing wuluh berdasarkan tes skala mutu hedonik. 
Dalam penelitian ini yang ingin dicapai adalah mengetahui kualitas sorbet buah belimbing wuluh dilihat dari segi tekstur dan rasa. Dan untuk mencapai tujuan peneliti menggunakan metode analisi deskriftif kuantitatif. Menurut Agung (1999) analisis deskriftif kuantitatif adalah suatu cara pengolahan data dengan cara menyusun secara sistematis dalam $\operatorname{Mean} \frac{(M)}{N}=\sum x$

\section{Keterangan:}

$\mathrm{M}$

$\sum x$

$\mathrm{N}$

$N$

$$
\begin{aligned}
& =\text { Mean (rata-rata) } \\
& =\text { Jumlah masing- } \\
& \text { masing skor } \\
& \text { tekstur, rasa) } \\
& =\text { Jumlah panelis }
\end{aligned}
$$

(Arikunto,2002)

Rumus pedoman konversi skala 3 (tiga)

$$
\begin{aligned}
& M+1 S D \longrightarrow M+3 S D \\
& M-1 S D \longrightarrow M+1 S D \\
& M-3 S D \longrightarrow M-1 S D
\end{aligned}
$$

Keterangan rumus:

$$
\begin{aligned}
\mathrm{M} & =\text { Mean } \\
\mathrm{SD} & =\text { Standar Deviasi } \\
& (\text { Koyan, 2011) }
\end{aligned}
$$

Keterangan :

$\mathrm{M}=$ Mean atau rata-rata yang dicari dengan rumus:

$\mathrm{M}=\frac{1}{2} \times$ (Skor Maksimum + Skor

SD = Standar Deviasi yang dicari dengan rumus:

$\mathrm{SD}=\frac{1}{6} \times$ (Skor Maksimum - Skor

Skor maksimum = 3

Skor minimum = 1 bentuk angka-angka mengenai objek yang diteliti untuk mendapat kesimpulan akhir. Setelah melakukan analisis data dengan metode deskriftif kuantitatif dari uji kualitas sorbet buah belimbing wuluh, sehingga didapatkan kesimpulan akhir, data dari uji kualitas tekstur dan rasa dipersentasekan menggunkan rumus sebagai berikut:

Adapun rumusnya yaitu:

Berdasarkan rumus di atas, maka data yang sudah terkumpul akan dicari konversinya. Sehingga mendapatkan hasil sebagai berikut:

$$
M=\frac{1}{2} \times \text { (Skor Maksimum }+ \text { Skor }
$$$$
M=\frac{1}{2} \times(3+1)
$$$$
M=2
$$

$\mathrm{SD}=\frac{1}{6} \times$ (Skor Maksimum - Skor

$$
\mathrm{SD}=\frac{1}{6} \mathrm{X}
$$

$$
S D=0,33
$$

Acuan tersebut digunakan untuk menentukan kualitas sorbet buah belimbing wuluh dilihat dari aspek tekstur dan rasa berdasarkan rumus pedoman konversi menggunakan skala 3 (tiga) adalah sebagai berikut :

Tabel 6. Skala 3 (tiga)

\begin{tabular}{cc}
\hline Rentang skor & Klasifikasi/predikat \\
\hline $2,33-3,00$ & Baik \\
$1,67-2,32$ & Cukup \\
$1,00-1,66$ & Buruk \\
\hline
\end{tabular}

\section{HASIL DAN PEMBAHASAN}

Pengumpulan data untuk penelitian ini dilaksanakan di Jurusan Pendidikan Kesejahteraan Keluaraga (tata boga), SMK N 2 Singaraja, SMK Pariwisata triatma jaya dan The Lovina Hotelpada tanggal 12-13 oktober 2017. Sorbet buah belimbing wuluh ini di uji kualitasnya dengan menggunakan resep standar sorbet mangga. Selanjutnya dilakukan uji 
mutu organoleptik terhadap sorbet buah belimbing wuluh untuk aspek tekstur dan rasa.

kualitas terhadap 25 orang panelis terlatih yang terdiri dari 2 orang Dosen Tata Boga di Jurusan Pendidikan Kesejahteraan Keluarga, 12 orang Guru SMK Negeri 2 Singaraja, 3 orang Guru SMK Pariwisata Triatma Jaya Singaraja, dan 8 orang cook yang berasal dari The Lovina Hotel. Data yang diperoleh dianalisis menggunakan teknik deskriptif kuantatif terhadap kualitas sorbet buah belimbing wuluh dilihat dari aspek tekstur dan rasa menggunakan kategori baik, cukup, buruk. Hasil penelitian menjelaskan tentang resep standar sorbet buah belimbing wuluh hingga diperoleh kualitas terhadap sorbet buah belimbing wuluh dilihat dari 2 aspek yaitu aspek tekstur dan aspek rasa. Proses pengolahan sorbet buah belimbing wuluh ini dimulai dengan tahapan persiapan bahan utama yaitu buah belimbing wuluh dan bahan-bahan lainnya. Dilanjutkan persiapan alat dan penimbangan bahan sesuai dengan hasil dari formulasi resep yang telah dilakukan oleh peneliti sehingga menghasilkan resep standar sorbet buah belimbing. Langkah kerja yang digunakan selama proses pengolahan sebelumnya telah disusun dalam lembar kerja. Lembar kerja merupakan langkah kerja yang harus dilaksanakan selama proses pengolahan sorbet buah belimbing wuluh. Berdasarkan hasil eksperimen sorbet dari buah belimbing wuluh yang dilakukan sebanyak 3 kali. Sebelum dilaksanakan uji kualitas terhadap produk sorbet berbahan dasar buah belimbing wuluh, terlebih dahulu dilakukan formulasi resep terhadap sorbet buah belimbing wuluh. Tujuan dari diadakannya formulasi resep adalah untuk mengetahui sorbet buah belimbing wuluh telah memenuhi kriteria sorbet secara umum. Penilaian terhadap sorbet buah belimbing wuluh dilakukan oleh peneliti dan dua orang dosen pembimbing. Adapun langkah-langkah pra eksperimen yang telah dilakukan oleh penulis adalah sebagai berikut:

Eksperimen yang pertama dilaksanakan pada tanggal 24 Februari
Data dalam penelitian ini seluruhnya dikumpulkan dengan menggunakan lembar observasi berupa lembar uji 2017. Pada eksperimen ini peneliti menggunakan resep dengan formulasi bahan sebagai berikut:
a. Buah belimbing wuluh
1400 gram
b. Gula pasir
c. Air
200 gram
d. Sari lemon
$700 \mathrm{ml}$
e. Glukosa
$70 \mathrm{ml}$
100 gram

Cara membuat :

1. Masukkan buah belimbing wuluh yang telah dipotong-potong menjadi 4 bagian kedalam blender dan haluskan.

2. Rebus air, gula dan air jeruk nipis sampai mendidih kemudian masukkan buah belimbing wuluh yang telah dihaluskan.

3. Tunggu sampai adonan dingin lalu masukkan adonan kedalam mesin pembuatan es krim selama 15 menit.

4. Sorbet belimbing wuluh siap disajikan Berdasarkan resep awal yang mengacu pada resep sorbet mangga, hasil yang didapatkan yaitu dari segi rasa sangat asam hal tersebut dikarenakan rasa asam daging buah belimbing wuluh yang mentah mengandung asam askobat dan vitamin $C$ selain itu penambahan sari lemon juga sangat mempengaruhi sehingga menghasilkan rasa yang sangat asam. Tekstur sorbet yang dihasilkan kasar dan berserat.

Eksperimen yang kedua dilaksanakan pada tanggal 18 Mei 2017. eksperimen ini peneliti menggunakan resep dengan formulasi bahan sebagai berikut:
a. Buah belimbing wuluh
700 gram
b. Gula pasir
c. Air 200 gram
d. Glukosa $100 \mathrm{ml}$ 100 gram

Cara membuat :

1. Masukkan buah belimbing wuluh yang telah dipotong-potong menjadi 4 bagian kedalam blender dan haluskan.

2. Rebus air dan gula sampai mendidih kemudian masukkan buah belimbing wuluh yang telah dihaluskan.

3. Tunggu sampai adonan dingin lalu masukkan adonan kedalam mesin pembuatan es krim selama 15 menit.

4. Sorbet belimbing wuluh siap disajikan. 
Jurnal Bosaparis: Pendidikan Kesejahteraan Keluarga

Volume 9, Nomor 1, Maret 2018

Dari uji coba yang kedua yang dilaksanakan pada tanggal 18 Mei 2017 dengan tidak menambahkan bahan yaitu sari lemon kemudian mengurangi bahan utama buah belimbing wuluh dan mengurangi jumlah air karena buah belimbing wuluh sudah memiliki kandungan air yang tinggi sebanyak $(94,1$ g). Hasil yang diperoleh sudah lebih baik namun rasa asam masih lebih dominan dari rasa manis dan tekstur yang dihasilkan kasar dan berserat. Eksperimen yang ketiga dilaksanakan pada tanggal 24 Mei 2017. Pada eksperimen ini peneliti menggunakan resep dengan formulasi bahan sebagai berikut:
a. Buah belimbing wuluh
500 gram
b. Gula pasir
300 gram
c. Air
$100 \mathrm{ml}$

1. Masukkan buah belimbing wuluh yang telah dipotong-potong menjadi 4 bagian kedalam blender dan haluskan.

2. Rebus air dan gula sampai mendidih kemudian masukkan buah belimbing wuluh yang telah dihaluskan

3. Tunggu sampai adonan dingin lalu masukkan adonan kedalam mesin pembuatan es krim selama 15 menit.

4. Sorbet belimbing wuluh siap disajikan

Untuk uji coba yang ketiga dengan menggunakan resep di atas, glukosa di ganti dengan gula pasir untuk memudahkan mencari bahan sorbet sehingga hasil yang diperoleh yaitu rasa manis keasaman sesuai dengan kriteria dari sorbet dan tekstur yang dhasilkan adalah kasar dan berserat. Hasil uji panelis terhadap kualitas sorbet buah belimbing wuluh sebagai berikut:

Cara membuat:

Table 7. Hasil tabulasi data uji kualitas sorbet buah belimbing wuluh

\begin{tabular}{|c|c|c|}
\hline \multirow{2}{*}{ Panelis } & \multicolumn{2}{|c|}{ Sorbet buah belimbing wuluh } \\
\cline { 2 - 3 } & Tekstur & Rasa \\
\hline 1 & 3 & 3 \\
\hline 2 & 2 & 3 \\
\hline 3 & 3 & 3 \\
\hline 4 & 2 & 2 \\
\hline 5 & 2 & 2 \\
\hline 6 & 2 & 3 \\
\hline 7 & 2 & 3 \\
\hline 8 & 2 & 3 \\
\hline 9 & 3 & 3 \\
\hline 10 & 1 & 2 \\
\hline 11 & 3 & 3 \\
\hline 12 & 2 & 3 \\
\hline 13 & 3 & 2 \\
\hline 14 & 3 & 3 \\
\hline 15 & 3 & 3 \\
\hline 16 & 3 & 3 \\
\hline 17 & 3 & 3 \\
\hline 18 & 3 & 2 \\
\hline 19 & 3 & 2 \\
\hline 20 & 3 & 2 \\
\hline 21 & 3 & 2 \\
\hline 22 & 3 & 2 \\
\hline 23 & 3 & 2 \\
\hline 24 & 3 & 3 \\
\hline 25 & 3 & 65 \\
\hline $2 \mathbf{X}$ & 66 & \\
\hline & & 3 \\
\hline & & 2 \\
\hline
\end{tabular}


Jurnal Bosaparis: Pendidikan Kesejahteraan Keluarga

Volume 9, Nomor 1, Maret 2018

Kualitas sorbet buah belimbing wuluh sebagai berikut:

1. Kualitas tekstur sorbet buah belimbing wuluh

$$
\begin{aligned}
& M=\frac{\sum x}{N} \\
& M=\frac{66}{25}
\end{aligned}
$$

$M=2.64$

Berdasarkan rumus di atas $M$ adalah Mean (rata-rata), selanjutnya $\sum \mathbf{X}$ adalah jumlah masing-masing skor terhadap kualitas tekstur sorbet buah belimbing wuluh dan $\mathrm{N}$ adalah jumlah subjek atau sampel. Berdasarkan hasil tabulasi data pada tabel 4.3 diperoleh $\sum \mathbf{X}$ terhadap sorbet buah belimbing wuluh adalah 66 dan $\mathrm{N}$ atau jumlah sampel adalah 25. Sehingga dapat dihitung $M$ atau rata-rata skor yang diperoleh terhadap kualitas tekstur sorbet buah belimbing wuluh adalah 66 dibagi 25 dan diperoleh hasil skor rata-rata 2,64.

$$
\begin{aligned}
M & =\frac{\sum x}{N} \\
M & =\frac{65}{25}
\end{aligned}
$$

$M=2,60$

Berdasarkan rumus di atas $M$ adalah Mean (rata-rata), selanjutnya $\sum \mathbf{X}$ adalah jumlah masing-masing skor terhadap kualitas rasa sorbet buah belimbing wuluh dan $\mathrm{N}$ adalah jumlah subjek atau sampel. Berdasarkan hasil tabulasi data pada tabel 4.3 diperoleh $\sum \mathbf{X}$ terhadap sorbet buah belimbing wuluh adalah 65 dan $\mathrm{N}$ atau jumlah sampel adalah 25. Sehingga dapat dihitung $M$ atau rata-rata skor yang diperoleh terhadap kualitas tekstur sorbet buah belimbing wuluh adalah 65 dibagi 25 dan diperoleh hasil skor rata-rata 2,60.

2. Kualitas rasa sorbet buah belimbing wuluh

Tabel 6. Hasil uji kualitas sorbet buah belimbing wuluh

\begin{tabular}{ccc}
\hline Aspek Yang Dinilai & \multicolumn{2}{c}{ Sorbet buah belimbing wuluh } \\
\cline { 2 - 3 } & Skor & Kategori \\
Tekstur & 2,64 & Baik \\
Rasa & 2,60 & Baik \\
\hline
\end{tabular}

Berdasarkan tabel 6. diperoleh hasil uji panelis sorbet buah belimbing wuluh menyaatakan kualitas sorbet buah belimbing wuluh dilihat dari aspek tekstur memperoleh skor 2,65 berada pada kategori baik sesuai dengan tolok ukur yaitu kasar dan berserat. Kualitas rasa sorbet buah belimbing wuluh memperoleh skor 2,60 berada pada kategori baik sesuai tolok ukur yaitu manis keasaman.

Berdasarkan dari hasil uji kualitas sorbet buah belimbing wuluh dilihat dari aspek tekstur dan rasa, dapat dilihat pada diagram batang dibawah ini.Diagram 4.1 Hasil uji kualitas sorbet buah belimbing wuluh ditinjau dari aspek tekstur dan rasa. 


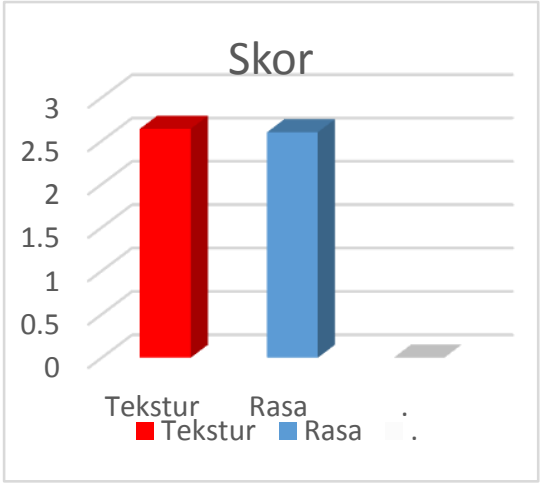

\begin{abstract}
Tekstur adalah jalinan atau penyatuan bagian-bagian sesuatu sehingga membentuk suatu benda (Kamus Besar Bahasa Indonesia, 2012). Dalam menentukan tekstur suatu produk makanan, dapat ditentukan dengan cara dipotong, diiris, maupun ditekan dengan ujung jari tangan atau meraba pada permukaan makanan. Tekstur dari suatu hidangan dapat mempengaruhi penampilan hidangan yang disajikan.
\end{abstract}

Dari hasil uji panelis yang dilakukan, diketahui bahwa sorbet buah belimbing wuluh dilihat dari aspek tekstur memperoleh skor rata-rata 2,64 dan sebanyak 17 orang panelis menyatakan tekstur dari sorbet buah belimbing wuluh kasar dan berserat, 7 orang panelis menyatakan dari segi aspek tekstur yang didapat tidak berserat dan 1 orang panelis menyatakan tidak berserat dan tidak kasar, sehingga kualitas sorbet buah belimbing wuluh berada dalam kategori baik sesuai dengan tolok ukur yang ditentukan.

Rasa adalah hasil respon terhadap suatu makanan atau minuman dari penilaian indra pencicip (Kamus Besar Bahasa Indonesia, 2012). Rasa dapat dipengaruhi oleh bahan yang digunakan. Sorbet umumnya memiliki rasa yang segar yaitu manis keasaman, sorbet buah dalam pembuatannya biasanya ditambahkan dengan gula dan asam sitrat atau bisa juga menggunakan sari lemon. Dalam penelitian ini menggunakan buah belimbing wuluh sebagai bahan utama dalam pembuatan sorbet.

Hasil uji kualitas sorbet buah belimbing wuluh dari aspek rasa yang diperoleh dari 25 orang panelis terlatih memperoleh skor rata-rata 2,60. Sebanyak 16 orang panelis menyatakan manis keasaman dan 9 orang panelis menyatakan dari aspek rasa sangat asam atau terlalu kecut. Hal ini menyebabkan kualitas rasa sorbet buah belimbing wuluh berada pada kategori baik sesuai dengan tolok ukur yang ditentukan. Dalam penelitian ini rasa yang sesuai dengan tolok ukur sorbet buah belimbing wuluh adalah memiliki rasa manis keasaman. Hal ini disebabkan karena karakteristik bahan utama yang digunakan memiliki rasa asam yang dipadukan dengan bahan tambahan berupa gula pasir untuk memperoleh rasa manis keasaman sesuai tolok ukur yang digunakan.

\section{SARAN}

1. Kepada peneliti lain hasil dari penelitian ini dapat dikembangkan kembali dengan meningkatkan penampilan dalam pengemasan serta daya simpan sorbet buah belimbing wuluh.

2. Kepada masyarakat daerah yang memiliki buah belimbing wuluh diharapkan dapat memanfaatkan buah belimbing wuluh sebagai produk olahan sehingga dapat meningkatkan nilai ekonomi dari buah belimbing wuluh.

\section{DAFTAR PUSTAKA}

Agung A.A. Gede. 1999. Metodologi Penelitian. Pendidikan Singaraja STKIP Negeri Singaraja

Agustin, F., dan Putri. D. R. 2014. Pembuatan jelly drink averrhoa blimbi L. (kajian proporsi belimbing wuluh: air dan konsentrasi karagenan).Tersedia pada http://jurnalmahasiswa.unesa.ac.id (diakses tanggal 18 Mei 2017)

Arikunto, Suharsimi. 2006. Prosedur Penelitian Suatu Pendekatan Praktek, Edisi Revisi 6. Jakarta : PT Reineka Cipta

Departemen Pendidikan Nasional. 2012. Kamus Besar Bahasa Indonesia pusat bahasa Edisi Ke-4. Jakarta : PT Gramedia Pustaka Utama. 
Jurnal Bosaparis: Pendidikan Kesejahteraan Keluarga

Volume 9, Nomor 1, Maret 2018

Faridah, anni dkk. 2008. Patiseri. Jakarta:

Direktorat Pembinaan Sekolah

Menengah Kejuruan, Direktorat

Jenderal Manajemen Pendidikan

Dasar dan Menengah,

Departemen Pendidikan Nasional.

Fitriani, shanti. 2008. Pengaruh suhu dan lama pengeringan terhadap beberapa mutu manisan Belimbing wuluh (Averrhoa bilimbi L.)kering. Tersedia pada https://ejournal.unri.ac.id (diakses tanggal 15 Mei 2017).

Koyan, I Wayan. 2011. Asesmen Dalam Pendidikan. Singaraja: Universitas Pendidikan Ganesha.

Lingga, P.1992. Bertanam Belimbing,cetakan ke VII. Jakarta: Penebar Swadaya.

Primarasa, Femina. 2009. Es krim, Sorbet dan Es loli. Jakarta: PT Gaya Favorit Press.

Rosita, Ernalia. 2016. Sorbet. Tesedia pada

http://errenscorner.blogspot.co.id/2 017/02/laporan-praktikum-

sorbet.html (diakses tanggal 18 April 2017)

Santosa, Djoko dan Didik Gunawan. 2005. Ramuan Tradisional Untuk Penyakit Kulit, cetakan ke VII. Jakarta: Penebar swadaya.

Soekarto, Tsoewarno. 1985. Penelitian Organoleptik. Jakarta: Bhratara Karya Aksara.

Subhadrabandhu, S. 2001. Under Utilized Tropical Fruits of Thailand. Food and Agriculture Organization of the United Nations Regional Office for Asia and the Pacific. Bangkok, Thailand. Tersedia pada http://www.fao.org/3/a-ab777e.pdf (diakses tanggal 22 April 2017).

Wijayakusuma, Hembing dan Setiawan Dalimartha. 2004. Ramuan Tradisional untuk Pengobatan Darah Tinggi, cetakan $x$. Jakarta: Penebar Swadaya.

Winneke. 2008. Sorbet Asam Jawa. Tersedia pada http//www.detikfood.com. (diakses tanggal 18 April 2017). 